\title{
Haemophilus influenzae, Beta-Lactamase Positive
}

National Cancer Institute

\section{Source}

National Cancer Institute. Haemophilus influenzae, Beta-Lactamase Positive. NCI

Thesaurus. Code 123478.

Any bacterial species identified as Haemophilus influenzae that produces the enzyme beta-lactamase. 